\title{
Natural Gas Security in China: A Simulation of Evolutionary Trajectory and Obstacle Degree Analysis
}

\author{
Mingjing Guo ${ }^{1,2,3}\left(\mathbb{D}\right.$, Yan $B u^{1,3, *(\mathbb{C}}$, Jinhua Cheng ${ }^{1,2,3}$ and Ziyu Jiang ${ }^{1}$ \\ 1 School of Economics and Management, China University of Geosciences, Wuhan 430074, China; \\ guomingjing@cug.edu.cn (M.G.); chengjinhua@cug.edu.cn (J.C.); jiangziyu@cug.edu.cn (Z.J.) \\ 2 Key Laboratory of Research on Land Resources Strategy, Ministry of Natural Resources of the China, \\ Beijing 100812, China \\ 3 Research Center of Resource and Environmental Economics, China University of Geosciences, \\ Wuhan 430074, China \\ * Correspondence: buyan10@cug.edu.cn; Tel.: +86-27-6788-3201
}

Received: 21 November 2018; Accepted: 20 December 2018; Published: 24 December 2018

\begin{abstract}
Studying the security status of China's natural gas supply and proposing a feasible coping strategy for enhancing that security is of great significance. We use a pressure-state-response (PSR) analysis framework and the exponential weighting method to make a systematic evaluation of China's natural gas security, predict the evolution of natural gas security combined with the GM(1,1) model, and use the obstacle degree model to diagnose the obstacles standing in the way of China's optimum natural gas security. China's natural gas comprehensive security index from 2006 to 2015 was between 0.627 and 0.740 , and it is predicted to land between 0.669 and 0.759 from 2016 to 2025. The barriers affecting China's natural gas security moving forward will be focused on urban development pressure, natural gas consumption growth pressure, supply-demand ratio, storage-production ratio, import price volatility for liquefied natural gas, and import dependence. We predict China's natural gas security will be characterized by a wave of advancement, and has certain periodicity. The main internal factors affecting China's natural gas security will shift from the rudimentary natural gas pipeline construction and gas storage facilities construction to the low availability of natural gas and urbanization, which will increase the pressure on natural gas supply and demand.
\end{abstract}

Keywords: natural gas security; evolution trajectory; obstacle degree; PSR model; exponential weighting method; $\mathrm{GM}(1,1)$ model

\section{Introduction}

In the coming decades, global economic growth is going to be heavily impacted by changes related to energy security, as global demand for energy continues to grow. According to the World Energy Outlook, with the United States moving steadily toward meeting almost all of its energy needs, the ballooning energy needs of the BRIC economies (Brazil, Russia, China, and India, but especially China and India) and the European Union are likely to be a major catalyst of growing energy demand [1]. Currently, energy demand has been growing faster than ever, particularly in developing countries, making energy security an integral part of national security and one of the key parameters for assuring a stable development of countries and regions [2]. With this global energy transition, issues related to the security of natural gas, a cleaner energy than oil, coal, and other fossil fuels, has attracted a great deal of attention from researchers and policymakers.

By population, China is the largest developing country in the world and boasts the second-largest economy, with 1.4 billion people and a GDP of 12.24 trillion (USD) in 2017. Given the size and scope of its populace and economy, China's natural gas usage has become the main driving force for the steep 
increase in global consumption. Moreover, natural gas is a critical action point for effectively controlling atmospheric haze and promoting the sustainable development of China's energy production and consumption [3].

In order to fulfill the goals of the 2030 Agenda for Sustainable Development and the Paris Agreement, the Chinese government has listed the development of its natural gas industry and infrastructure as a significant part of its strategy to optimize its energy structure and cope with environment pollution (such as the aforementioned haze) and climate change. However, China's natural gas security has been changing from the perspective of supply and demand. Supply shortages caused by a "squeeze on natural gas" have frequently occurred, which has greatly threatened the national energy security. The causes of the gas shortage include extreme weather, poor infrastructures such as pipeline and storage, or the excessive radicalization of the energy policy. For instance, the government had implemented a coal-to-gas Policy across north China in the winter of 2017 due to heavy haze pollution in recent years. The coal ban has led to not only a rush to switch to natural gas, but also a shortage of fuel and record-breaking fuel prices since the start of the winter heating season in mid-November, 2017. This condition resulted in the rise of global liquefied natural gas (LNG) prices. Therefore, in the context of global energy transformation and market condition variation, policy makers must consider the following questions seriously: What are the key factors affecting China's natural gas security in the future? What is the medium and long-term situation of natural gas security? How do you maintain sustainable development of the natural gas market?

Despite the importance of energy security, several authors have pointed out that the term is not clearly defined [4]. Meanwhile, with great changes in the supply and demand status of the international energy market, the definition of "energy security" has broader significance.

Based on the previous research, this paper defined the concept of natural gas security, followed by constructing the "pressure-state-response" model that evaluates China's natural gas security systematically using historical data. Additionally, the GM(1,1) model is used to predict the evolution trajectory of natural gas security in China, and an obstacle degree model is constructed to diagnose the impacts of the above-mentioned key factors on natural gas security.

\section{Literature Review}

With the popularity of energy security studies in recent years, natural gas security has unsurprisingly followed suit, and has also become a research hotspot in its own right. The most important aspect of research on natural gas security is to clarify the definition of natural gas security and to select methods suitable for it.

Energy security is a key factor for sustaining the socioeconomic and industrial development of a country [5]. Energy security is a priority for almost all countries, even though there is still no widely accepted definition of energy security [6]. There are a number of definitions which can be divided into those focused on the security of supply (short-term energy security) and definitions which take account of a broader concept of energy security (long-term energy security). Dyer and Trombetta state that "energy security is in association with national security and defines the continuous availability of energy in varied forms, in sufficient quantities and at affordable prices" [7]. Winzer analyzed 36 definitions of energy security and he himself defined energy security as "the continuity of energy supplies relative to demand" [4]. The European Commission defines energy security as "the ability to ensure that future essential energy needs can be met, both by means of adequate domestic resources worked under economically acceptable conditions or maintained as strategic reserves, and by calling upon accessible and stable external sources supplemented where appropriate by strategic stocks" [8]. The International Energy Agency has developed a short-term and long-term approach to energy security, which defines energy security as "an uninterrupted availability of energy sources at an affordable price" [9]. The short-term approach considers energy security as the system's ability to meet the particular country's energy needs, whereby the absolute focus is on the security of supply [10]. New approaches to energy security highlight the need to take into further consideration the environmental and social 
aspects as well [11]. A more compound and, at the same time, wider definition by Cherp and Jewell, states that energy security is low vulnerability of vital energy systems [12]. Ultimately, energy security 'takes on different specificities depending on the country (or continent), timeframe or energy source to which it is applied' [13]. Thus, at various levels of analysis energy security 'may contain similar notions of availability, adequacy, affordability and sustainability but the specificities of each will understandably differ at any point in time' $[13,14]$.

Natural gas is generally considered as a clean and efficient fossil fuel, making it attractive as an energy source [15], and it is also widely recognized as being a key transitional route in the move towards future sustainable energy source systems. In recent years, security issues related to natural gas have heightened around the world. However, most existing literature focuses on the perspective of supply security. It is mainly divided into three aspects: Supply security [16-21], supply interruption risk [22-24], and demand forecast [25-30]. Additionally, some authors are concerned about pricing issues to secure the gas market [31-38]. However, natural gas security is obviously not just the security of supply and demand, nor is it just a pricing issue. Like energy security, it contains various issues such as supply and demand status, market pricing, resource reserves, and even the political security of a country. Therefore, based on the definition of energy security from previously mentioned authors, this paper concludes that natural gas security is a state, meaning that a country or region obtains a sufficient, reliable, affordable, and continuous supply at a specified time and place, that is: Adequate natural gas resources to meet the needs of national or regional economic development, social stability, and national security.

Many studies so far have been proposed to evaluate, assess, and analyze energy security. Kiriyama and Kajikawa [39] and Umbach [40] presented a multilayered analysis of energy security research and the energy supply process, as well as implications for global energy security. Moreover, there are various methodologies of energy security [41,42] as well as a plethora of methods, indicators, and measures often used in the research literature [43-46]. Smart grids or nuclear energy security are of special interest [47,48]. In addition, a system dynamics approach is often involved for assessing the whole complexity of these issues [49].

As with energy security research, a number of authors have presented various methods to study natural gas security. Zhang et al. [16] and Lu et al. [17] applied an ecological network analysis to simulate the security level of natural gas supply systems and evaluation systems. Darko Pavlovića et al. [18] proposed a composite index including indicators of Energy Import Dependency Index, Energy Intensity, Gross Inland Consumption, Index of National Economy Dependence on Natural Gas, Herfindahl-Hirschman Index, and Shannon-Wiener Index to measure the security of the natural gas supply. Biresselioglu et al. [19] used principal component analysis to establish a supply security index and assessed the security of natural gas supplies in 23 natural-gas-importing countries. Istemi Berk et al. [20] evaluated the historical determinants and implications of Turkey's natural gas import dependency. Based on the principle component analysis (PCA) methodology to construct a natural gas import vulnerability index (NGIVI), Geng et al. [21] determined optimal portfolio strategies for liquefied natural gas (LNG) importation based on multi-objective optimization models from a supply chain perspective. By considering the various significant risks, the new analytical framework proposed offers an effective tool for making decisions about the optimal portfolio for LNG importation. Ibrahim Abada et al. [22] analyzed the impact of uncertain disruptions in gas supply upon gas retailer contracting behavior, and consequent price and welfare implications in a gas market characterized by long-term gas contracts using a static Cournot model. Lochner [23] presented an infrastructure and dispatch model of the European gas market, and confirmed the importance of gas stocks in mitigating risks from supply disruptions. Flouri et al. [24] investigated how a natural gas supply interruption from Algeria, the EU's third-largest supplier, would affect European natural gas security with regards to natural gas demand satisfaction. Lise et al. [25] focused on interactions among demand, supply, and investments in natural gas corridors, namely pipeline transport, LNG, and storage facilities. Cabalu [26] examined the relative vulnerability to natural gas supply disruptions of seven 
gas-importing countries in Asia for the year 2008. Holz et al. [27] applied the EMF 23 study design to simulate the effects of the reference case and the scenarios on European natural gas supplies to 2025. Suganthi et al. [28] reviewed the various energy demand forecasting models, while Parikh et al. [29] analyzed and estimated the projected demand of natural gas in the next two decades in the context of changing government policies regarding the fertilizer industry. Wang et al. [30] predicted China's natural gas production trends in different scenarios and forecasted natural gas demand, and posited that the exploitation of unconventional natural gas will greatly improve China's annual natural gas production, and that natural gas will enable more time and space for renewable energy development.

Based on the above definitions, the core of natural gas security evaluation is to: (1) Sift the factors affecting security; (2) classify the factors; (3) track the internal relations among the factors; and (4) explain the processes of different factors. In order to build the natural gas security evaluation model, this paper cites the PSR model, a sustainable development mechanism proposed by OECD [50], and utilizes the logic of "pressure-state-response" causality to analyze the pressure (social, environmental, resource-related) faced by natural gas development. The current state of natural gas in China (resource endowment, market state, supply guarantee) and the country's response measures (resource development and emergency guarantee) to the current pressure of natural gas development are expounded from three perspectives.

In this paper, an exponential weighting method is used to calculate the natural gas security index, and the GM(1,1) model is used to forecast China's natural gas security trend in 2016-2025. Finally, we propose an obstacle model to measure the impact of various indicators on the natural gas security index in different years.

\section{China's Natural Gas Security Comprehensive Evaluation System}

\subsection{Model Constructing}

The research core of natural gas security evaluation is to screen the factors that affect the security of natural gas, classify the factors to trace their inner relationship, and explain the influential processes of different factor functions. In order to construct a comprehensive evaluation model of natural gas security, this work recommends a conceptual framework that can reflect a sustainable development mechanism developed by OECD, which is the PSR model. The PSR model makes use of the causal relationship logic of 'cause-effect-response' to elaborate the regulation and control process and mechanism of sustainable development from aspects of what happened, why, and how to respond. The PSR model suggests that human activities have brought pressure to the environment $(\mathrm{P})$, affected the quality of the environment and the quantity of natural resources (S), and society changes people's behavior and consciousness to deal with these changes through the environment, macroeconomic, and department policy (R). The three subsystems of pressure, state and response are not independent, but interacting. Utilizing the PSR concept framework helps to explain the interactional process and results of different factors affecting the security of natural gas, uncover the inner mechanism therein, and lay the foundation for evaluating natural gas security posture objectively [51].

The PSR comprehensive evaluation model of natural gas security is a general framework that reflects the interdependent and interactional relationship between resources, environment, targets of social economic development, and resource decision making. The rapid development of the social economy has brought about huge pressure to the security of natural gas (P). Taking advantage of natural gas exhaustively has changed the natural gas reserve and utilization conditions (S). The natural gas security pressure demands society to take responding solutions (R), such as improving natural gas reserves to boost national regulating ability of the natural gas supply. Figure 1 shows the conceptual model of natural gas security based on the PSR theory. 


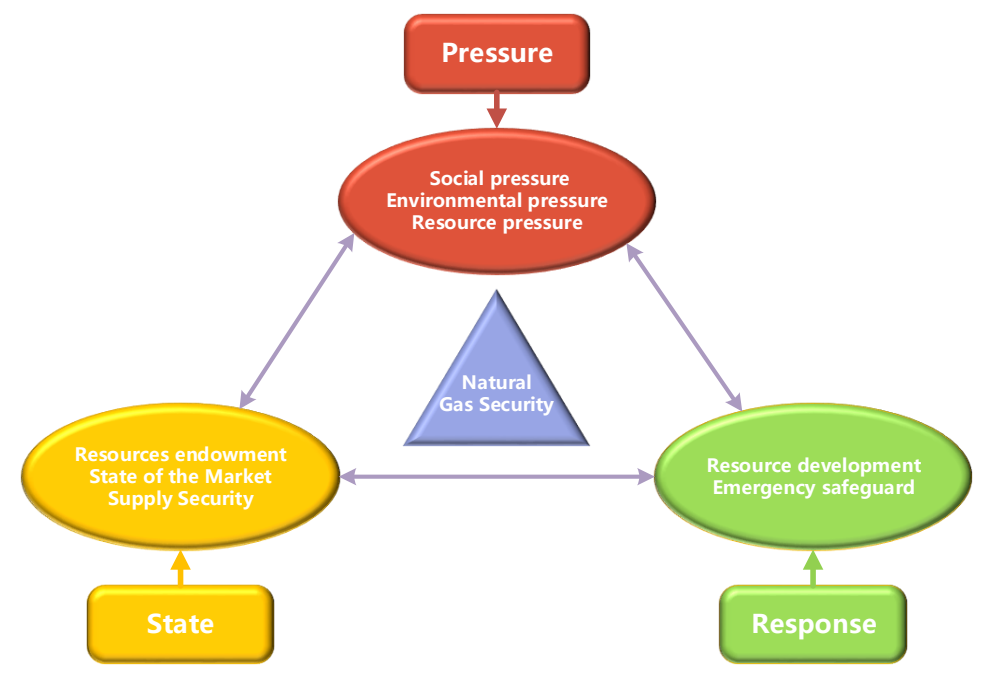

Figure 1. PSR (pressure-state-response) model framework.

\subsection{Building a Comprehensive Evaluation Index System}

Natural gas security based on the PSR model is evaluated from aspects of pressure, state, and response, respectively.

\section{(1) Pressure Indicator System (P)}

Natural gas is a kind of low-carbon, cleaner burning fuel, and plays an important role in energy transition and environmental improvement. Economic development, population growth, and urbanization processes promote natural gas consumption and put pressure on the natural gas supply. The natural gas pressure indicator system established in this paper contains four dimensions: Social pressure, environmental pressure, and resource pressure.

\section{(2) State Indicator System (S)}

China is in a state of energy transformation, where natural gas resources are derived from domestic and imported gas and are supplied to local governments through pipeline transportation and storage facilities. On the supply side of the natural gas market we should consider the price of natural gas domestically and internationally. Since imports of natural gas involve national political diplomacy, the natural gas safety status indicator system established in this paper contains three dimensions of price: Resource endowment, market status, and supply security.

\section{(3) Response Indicator System (R)}

Facing the pressure of natural gas supply and demand, the government-led response measures mainly start from the financial support for natural gas resource exploration and development and the level of national strategic reserve. The national strategic reserve should provide emergency protection measures for issues such as gas shortage. Therefore, this paper establishes a natural gas safety response indicator system from two dimensions of resource development and emergency support.

Based on the above theoretical analysis, this paper constructed three primary indices, eight secondary indices, and 19 three-level indicators. Table 1 shows the natural gas security evaluation index system based on the PSR model. 
Table 1. Natural gas security evaluation index system based on the (pressure-state-response) PSR model.

\begin{tabular}{|c|c|c|c|c|}
\hline Goal & $\begin{array}{l}\text { Primary } \\
\text { Indices }\end{array}$ & Secondary Indices & Three-Level Indicator & Indicator Description \\
\hline \multirow{19}{*}{$\begin{array}{l}\text { Natural Gas } \\
\text { Comprehensive } \\
\text { Security Index }\end{array}$} & \multirow{8}{*}{ Pressure } & \multirow{3}{*}{ Social pressure } & Population growth pressure (P1) & Natural population growth rate \\
\hline & & & Urban development pressure (P2) & Urbanization rate \\
\hline & & & Economic growth pressure (P3) & GDP growth rate \\
\hline & & \multirow{3}{*}{ Environmental pressure } & $\begin{array}{l}\mathrm{CO}_{2} \text { emission reduction } \\
\text { pressure }(\mathrm{P} 4)\end{array}$ & $\mathrm{CO}_{2}$ emissions per unit of GDP \\
\hline & & & $\mathrm{SO}_{2}$ pollution pressure ( $\left.\mathrm{P} 5\right)$ & $\mathrm{SO}_{2}$ emissions per unit of GDP \\
\hline & & & $\begin{array}{l}\text { Environmental pollution control } \\
\text { pressure (P6) }\end{array}$ & $\begin{array}{l}\text { Environmental pollution investment as a share } \\
\text { of GDP }\end{array}$ \\
\hline & & \multirow{2}{*}{ Resource pressure } & $\begin{array}{l}\text { Increased pressure on natural gas } \\
\text { consumption (P7) }\end{array}$ & Natural gas consumption growth rate \\
\hline & & & The ratio of supply to demand (P8) & $\begin{array}{l}\text { Ratio of natural gas production to natural gas } \\
\text { consumption }\end{array}$ \\
\hline & \multirow{8}{*}{ State } & \multirow{2}{*}{ Resources endowment } & Reserve-production ratio (S1) & $\begin{array}{l}\text { The ratio of residual natural gas reserves in } \\
\text { that year to natural gas production in that year }\end{array}$ \\
\hline & & & World reserve ratio (S2) & $\begin{array}{l}\text { The ratio of China's natural gas reserves to the } \\
\text { world's reserves }\end{array}$ \\
\hline & & \multirow{4}{*}{ State of the market } & Market concentration (S3) & $\begin{array}{l}\text { The proportion of natural gas imported by the } \\
\text { three or five countries or regions with the } \\
\text { largest volume of imports }\end{array}$ \\
\hline & & & Domestic price volatility (S4) & $\begin{array}{l}\text { Take the average of the gas price volatility of } \\
\text { each province }\end{array}$ \\
\hline & & & Price volatility of LNG import (S5) & $\begin{array}{l}\text { Ratio of price difference between current and } \\
\text { base period natural gas import and base period } \\
\text { natural gas import }\end{array}$ \\
\hline & & & Import dependence (S6) & $\begin{array}{l}\text { The ratio of natural gas imports to total natural } \\
\text { gas consumption }\end{array}$ \\
\hline & & \multirow{2}{*}{ Supply guarantee } & $\begin{array}{l}\text { Construction of natural gas } \\
\text { pipeline (S7) }\end{array}$ & The length of natural gas pipeline \\
\hline & & & Gas guarantee rate (S8) & $\begin{array}{l}\text { The ratio of actual natural gas supply to } \\
\text { natural gas consumption }\end{array}$ \\
\hline & \multirow{3}{*}{ Response } & Resource development & $\begin{array}{l}\text { Natural gas investment and } \\
\text { development accounts for the } \\
\text { proportion of oil and gas } \\
\text { development investment (R1) }\end{array}$ & $\begin{array}{l}\text { Ratio of investment in natural gas development } \\
\text { and investment in oil and gas development }\end{array}$ \\
\hline & & & Natural gas storage capacity (R2) & National natural gas strategic reserve \\
\hline & & Emergency guarantee & $\begin{array}{l}\text { The amount of natural gas that can } \\
\text { be supplied (R3) }\end{array}$ & The level of natural gas available that year \\
\hline
\end{tabular}

\section{Materials and Methods}

\subsection{Exponential Weighting Method}

\subsubsection{Calculation of Index Weight}

Entropy weight method was used to determine the index weight. Entropy method is a commonly used objective weighting method, which directly uses the inherent information of the evaluation index to weight the index, reduces the degree of subjectivity of the commonly used evaluation methods, and replaces the objective analysis of data structure with stronger explanatory power. The main calculation steps followed are:

- It was assumed that there are $\mathrm{m}$ evaluation objects, each of which has $\mathrm{n}$ indicators, and the original judgment matrix was constructed: $R=\left(x_{i j}\right)_{m \times n}$.

- Standardization of the original data matrix, elimination of indexes between different units, and the influence of different measures are considered, in order to get standardization of every index score matrix $\bar{R}=\left(r_{i j}\right)_{m \times n^{\prime}}$ Where $r_{i j}$ is the standard value of the $j$-th evaluation object in the $i$-th evaluation index, and $r_{i j} \in[0,1]$.

For forward indicators:

$$
r_{i j}=\frac{x_{i j}-\min \left\{x_{i j}\right\}}{\operatorname{man}\left\{x_{i j}\right\}-\min \left\{x_{i j}\right\}}
$$


For negative indicators:

$$
r_{i j}=\frac{\operatorname{man}\left\{x_{i j}\right\}-x_{i j}}{\operatorname{man}\left\{x_{i j}\right\}-\min \left\{x_{i j}\right\}}
$$

- $\quad$ The entropy weight of the $j$-th evaluation index $w_{j}$ :

$$
w_{j}=\left(1-H_{j}\right) / \sum_{j=1}^{n}\left(1-H_{j}\right)
$$

\subsubsection{Calculation of Natural Gas Comprehensive Security Index}

We studied the security index according to Zhu et al. [52] but with significant improvements. According to the trend of the evaluation index and the "wooden barrel principle", the computation of the security index was divided into the following two cases:

For forward indicators:

$$
P\left(X_{i}\right)=\left\{\begin{array}{cc}
1 & X_{i} \geq 2 S_{i} \\
\frac{X_{i}}{2 s_{i}} & X_{i}<2 S_{i}
\end{array}\right.
$$

For negative indicators:

$$
P\left(X_{i}\right)=\left\{\begin{array}{cc}
1 & X_{i} \leq S_{i} \\
2-\frac{X_{i}}{s_{i}} & S_{i}<X_{i} \leq 2 S_{i} \\
0 & X_{i}>2 S_{i}
\end{array}\right.
$$

where in Equations (4) and (5), $X_{i}(i=1,2,3, \cdots, n)$ is the actual value of evaluation index, $S_{i}$ is the arithmetic mean, and $P\left(X_{i}\right)$ is the security index.

Finally, the formula for calculating the comprehensive security index of natural gas was obtained by exponential weighting:

$$
E=\sum_{j=1}^{n} W_{j} \times P_{i j}
$$

$E$ is the comprehensive security index of natural gas, $W_{j}$ is the weight of the indicator, and $P_{i j}$ is the security index of each indicator.

\section{2. $G M(1,1)$ Model}

Grey prediction is a method for predicting systems with uncertain factors. The GM(1,1) model is the most commonly used grey dynamic prediction model. By establishing a mathematical model for quantitative analysis, the raw data that looks disordered on the surface is processed to discover its inherent regularity. The model only requires time series data and has fewer restrictions on the research object of "poor information", convenient operation, and high modeling precision, so it is widely used in prediction research in various fields. The basis of the grey prediction in the $\mathrm{GM}(1,1)$ model is the two " 1 "s represent the first-order equation and a variable, respectively, indicating that the model is essentially a univariate first-order differential equation. The model calculation steps are as follows:

- Let time series $X_{0}=\left\{x_{0}(1), x_{0}(2), x_{0}(3), \cdots, x_{0}(k)\right\}$ have $k$ observations, Generate a new sequence $X_{1}=\left\{x_{1}(1), x_{1}(2), x_{1}(3), \cdots, x_{1}(k)\right\}$ by accumulating the original sequence, the corresponding differential equation of the $\operatorname{GM}(1,1)$ model is:

$$
\frac{d X_{1}}{d t}+a X_{1}=\mu
$$

where: $a$ is the development gray number; $\mu$ is the endogenous control gray number. 
- Use matrix $X_{1}$ and $X_{0}$ to create matrix $B$ and matrix $Y_{n}$, respectively:

$$
\begin{gathered}
B=\left[\begin{array}{cc}
-\frac{1}{2}\left(x_{1}(1)+x_{1}(2)\right) & 1 \\
\vdots & \vdots \\
-\frac{1}{2}\left(x_{1}(k-1)+x_{1}(k)\right) & 1
\end{array}\right] \\
Y_{n}=\left[x_{0}(2), x_{0}(3), x_{0}(4), \cdots, x_{0}(k)\right]^{T}
\end{gathered}
$$

According to the matrices $B$ and $Y_{n}$, the parameters $a$ and $\mu$ are obtained by least squares fitting:

$$
\widehat{\alpha}=\left(\begin{array}{l}
a \\
\mu
\end{array}\right)=\left(B^{T} B\right)^{-1} B^{T} Y_{n}
$$

- Solve the differential equation and get the prediction equation:

$$
\widehat{X}_{0}(k+1)=\widehat{X}_{1}(k+1)-\widehat{X}_{1}(k)
$$

The accuracy of the gray prediction formula was tested. As shown in Table 2, if both $p$ and $c$ are within the allowable range, the predicted value of the indicator can be calculated. Otherwise, the formula needs to be corrected by analyzing the residual sequence.

Table 2. GM(1,1) model accuracy test standard.

\begin{tabular}{ccccc}
\hline Model Accuracy Level & Good & Qualified & Barely Qualified & Unqualified \\
\hline$c$ & $c \leq 0.35$ & $0.35<c \leq 0.5$ & $0.5<c \leq 0.65$ & $c>0.65$ \\
$p$ & $p \geq 0.95$ & $0.8 \leq p<0.95$ & $0.7 \leq p<0.8$ & $p<0.7$ \\
\hline
\end{tabular}

\subsection{Obstacle Model}

On the basis of China's natural gas security assessment, determining the influencing factors of China's natural gas security, conducting diagnosis and analysis of influencing factors, and proposing relevant adjustment policies and measures will help achieve sustainable development of natural gas and better safeguard China's natural gas security. Based on the obstacle model, this paper introduces factor contribution, index deviation, and obstacle degree to diagnose the obstacle factors affecting natural gas security. The calculation method is as follows:

$$
Q_{j}=\frac{r_{i j} \times w_{j}}{\sum_{j=1}^{n} r_{i j} \times w_{j}} \times 100 \%
$$

In the formula, $Q_{j}$ is the index obstacle degree, and $Q_{j} \geq 5 \%$ is the criterion for dividing the influence factor; $r_{i j}$ is the index deviation degree, $r_{i j}=1-X_{i j}^{\prime}$, $X_{i j}^{\prime}$ is the normalized value of the individual indicator; $w_{j}$ is the factor contribution (the individual indicator weights).

\subsection{Data Source}

After the adjustment of the national energy strategy, natural gas has been imported since 2006. Therefore, data from 2006 to 2015 were selected for comprehensive evaluation. The relevant index data came from the BP Statistical Yearbook of World Energy [53], China Statistical Yearbook 2006-2016 [54], China Energy Statistical Yearbook 2006-2016 [55], and China Urban Construction Statistical Year book 2006-2016 [56]. The GDP was calculated according to the constant price in 2005, and the missing data of individual index terms were estimated by analogy or interpolation. Note: Due to the availability and accessibility of data, this study did not include Taiwan, Hong Kong and Macau. 


\section{Results}

\subsection{Results}

\subsubsection{China's Natural Gas Security Assessment}

The change in the natural gas comprehensive security index reflects the evolutionary trajectory of China's natural gas security. The data of natural gas security evaluation indicators were collected, and the China national natural gas comprehensive security index was calculated by the exponential weighting method. The evolution trajectory is shown in Figure 2. From 2006 to 2015, China's natural gas comprehensive security index is between 0.627 and 0.740 . Only from 2008 to 2011, the natural gas security level exceeded 0.7, meaning the natural gas security level was low and had obvious fluctuation. From 2006 to 2009, China's natural gas security level demonstrated a clear upward trend. From 2006 to 2008, the security level of natural gas accelerated, and it decelerated from 2008 to 2009 , then peaked at a level of 0.740 in 2009 . From 2009 to 2014 , the annual natural gas security level has been in decline; slowly, at first, from 2009 to 2011, then rapidly from 2011 to 2014, with the most marked decline occurring between 2011 and 2012. After the evolution of the first cycle of rising and falling security levels, the natural gas security level rebounded again between 2014 and 2015 .

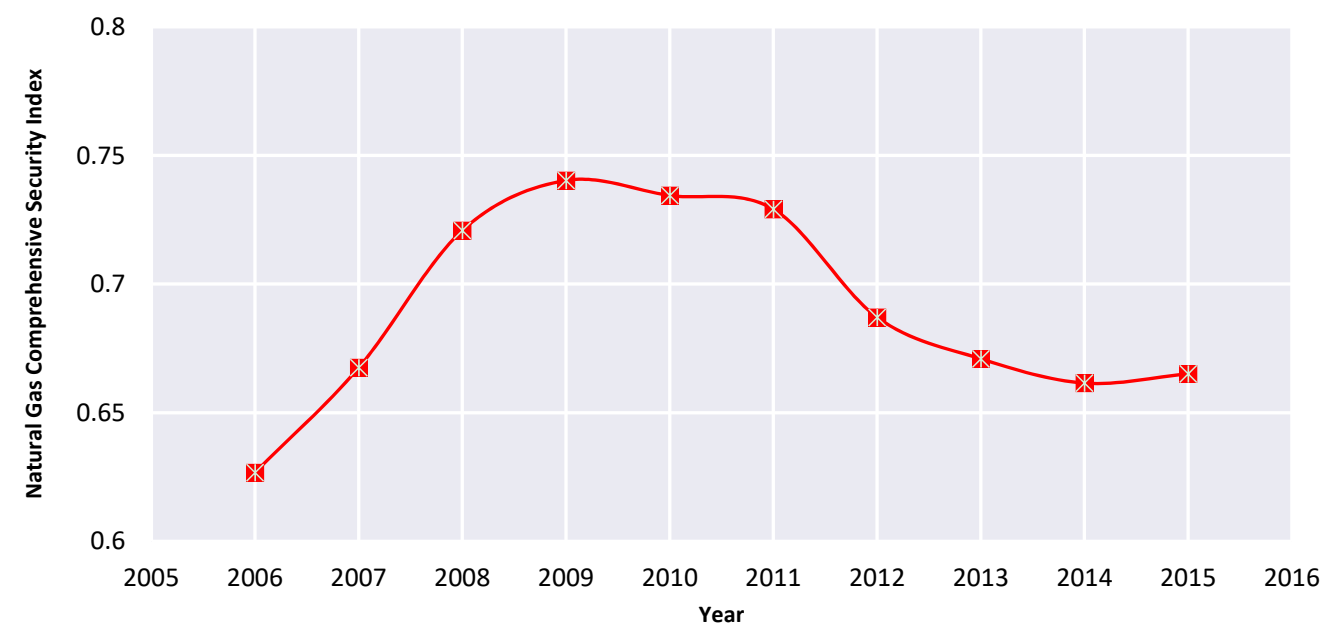

Figure 2. China's natural gas security evolution track from 2006 to 2015.

\subsubsection{China's Natural Gas Security Forecast}

From 2006 to 2015, China's natural gas security comprehensive index showed obvious fluctuation. In order to further explore the future evolution of China's natural gas security, this paper used a GM(1,1) model to predict China's natural gas comprehensive security index. The simulation accuracy of each evaluation index is shown in Table 3. Except for the simulation level of population growth rate (P1), which is poorly qualified, the simulation level of other evaluation indexes is well qualified, and the average relative error value is less than $20 \%$, so the model can be predicted. This paper predicts that China's population growth rate will fluctuate around 0.5\% from 2016 to 2025 through the GM(1,1) model. This prediction result is similar to that of Mao et al. [57]. Therefore, although the simulation results of population growth rate are poorly qualified, the prediction results can be included in the natural gas security evaluation. 
Table 3. Simulation accuracy values of natural gas security assessment indicators.

\begin{tabular}{|c|c|c|c|c|}
\hline Indices & $c$ & $p$ & Relative Error & Rank \\
\hline Population growth pressure (P1) & 0.6268 & 0.73 & 1.15 & Barely qualified \\
\hline Economic growth pressure $(\mathrm{P} 3)$ & 0.4270 & 0.82 & 7.09 & Qualified \\
\hline $\mathrm{CO}_{2}$ emission reduction pressure (P4) & 0.1497 & 1 & 2.74 & Good \\
\hline Environmental pollution control pressure (P6) & 0.5682 & 0.81 & 5.78 & Qualified \\
\hline Increased pressure on natural gas consumption (P7) & 0.1745 & 1 & 7.63 & Good \\
\hline The ratio of supply to demand (P8) & 0.1371 & 1 & 1.98 & Good \\
\hline Domestic price volatility (S4) & 0.2078 & 1 & 2.85 & Good \\
\hline Price volatility of LNG import (S5) & 0.3773 & 1 & 10.55 & Good \\
\hline Import dependence (S6) & 0.3365 & 1 & 17.99 & Good \\
\hline Construction of natural gas pipeline (S7) & 0.0596 & 1 & 2.11 & Good \\
\hline Gas guarantee rate (S8) & 0.3476 & 0.9 & 2.45 & Qualified \\
\hline Natural gas investment and development accounts for the proportion of oil and gas development investment (R1) & 0.2171 & 1 & 3.16 & Good \\
\hline Natural gas storage capacity (R2) & 0.3027 & 1 & 5.67 & Good \\
\hline
\end{tabular}

The exponential weighting method was used to calculate the predicted value of China's natural gas comprehensive security index from 2016 to 2025, and from that calculation the evolutionary trajectory of China's natural gas security from 2006 to 2025 was obtained. As shown in Figure 3, it is not difficult to observe that China's natural gas comprehensive security is characterized by an upward trend along with a certain pattern of periodicity. China's natural gas comprehensive security index is between 0.669 and 0.759 from 2016 to 2025. Except for the comprehensive security index of natural gas in 2016, 2017, and 2025, which is lower than 0.7 , the natural gas comprehensive security index in other years is higher than that 0.7 . Specifically, the natural gas comprehensive security index is predicted to see a steady upward trend from 2015 to 2021, and the natural gas comprehensive security index will reach a peak of 0.759 in 2021 . After that, the natural gas comprehensive security index shows a downward trend. Therefore, according to the current development trend, this paper predicts China's natural gas comprehensive security will be weakened (after a slight improvement) in the next ten years. Based on this prediction, it is necessary to analyze the obstacles during the forecast period to provide targeted solutions.

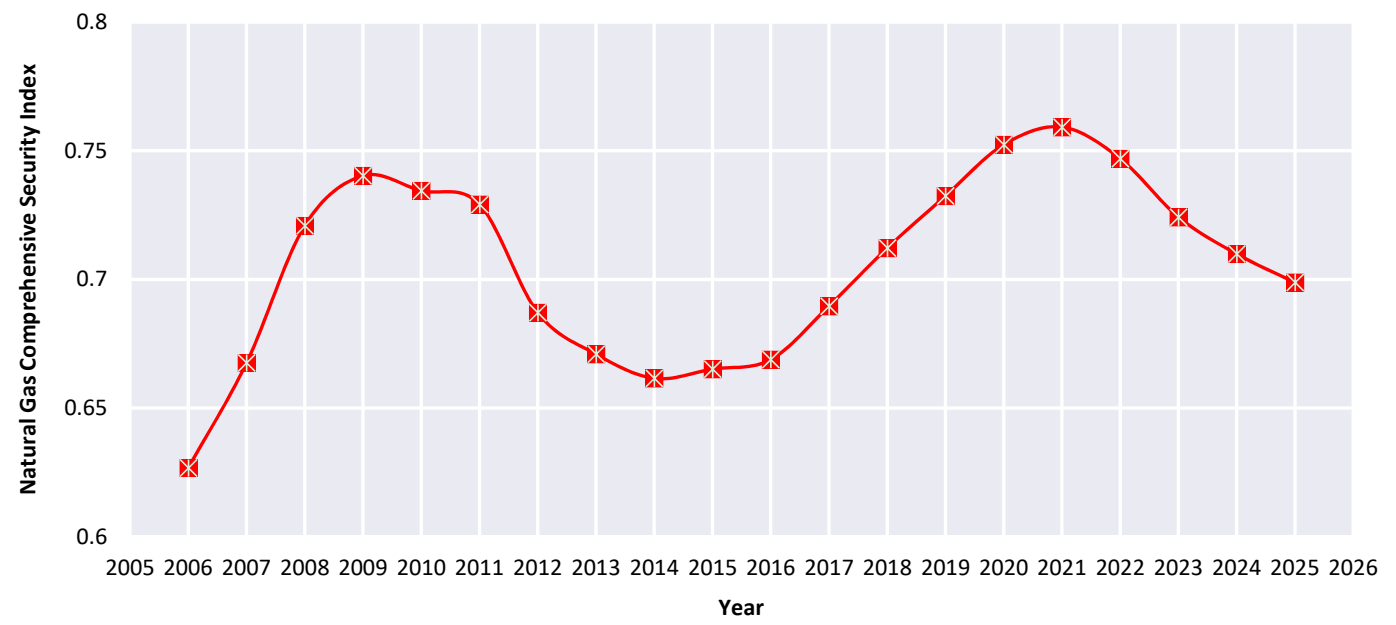

Figure 3. China's natural gas security evolution track map from 2006 to 2025.

\subsection{Discussion}

\subsubsection{Obstacle Degree Analysis on China's Natural Gas Security from 2006 to 2015}

Different from previous literature, in view of the low natural gas comprehensive security index and obvious fluctuations, this paper uses the obstacle model to further explore the key factors affecting natural gas security. As shown in Figure 4, from 2006 to 2015, the key barriers to the natural gas comprehensive security index are world reserve ratio (S2), market concentration (S3), natural gas 
pipeline construction (S7), gas source guarantee rate ( S8), natural gas storage capacity (R2), natural gas supply (R3), population growth pressure (P1), urban development pressure (P2), economic growth pressure (P3), $\mathrm{CO}_{2}$ emission reduction pressure (P4), sulfur dioxide Pollution pressure (P5), environmental pollution control pressure (P6), supply-demand ratio (P8), reserve-production ratio (S1), and resource development (R1). These are the main factors that caused the natural gas security index to show significant fluctuation during this time period. The essential reason for the low level of China's natural gas comprehensive security during this period was that China's natural gas resource endowment was rather weak compared with continuously increasing demand, natural gas infrastructure construction lagged behind the need, and resource development efforts and emergency support levels were low. Other factors such as social pressure, environmental pressure, and resource pressure were not the key reasons for the low level of natural gas security during those ten years. Specifically, the average obstacle degree of natural gas pipeline construction (S7) was 12.85\%, the average obstacle degree of gas source guarantee rate (S8) was $12.66 \%$, and the average obstacle degree of natural gas supply available quantity (R3) was $10.24 \%$. The average obstacle degree of market concentration (S3) was $7.73 \%$, the average obstacle degree of natural gas storage capacity (R2) was $7.30 \%$, and the average obstacle degree of world reserve ratio (S2) was $6.97 \%$, indicating that a lack of infrastructure was the definitive impact on China's natural gas security at that time. The internal factors were the regression of China's natural gas pipeline construction and gas storage facilities construction. Since 2006, China has started to import natural gas, with the source of the imports concentrated in several countries [3]. The market concentration is high, and political risks affect strategic security of natural gas resources in China. Market concentration is a major external factor affecting China's natural gas security.

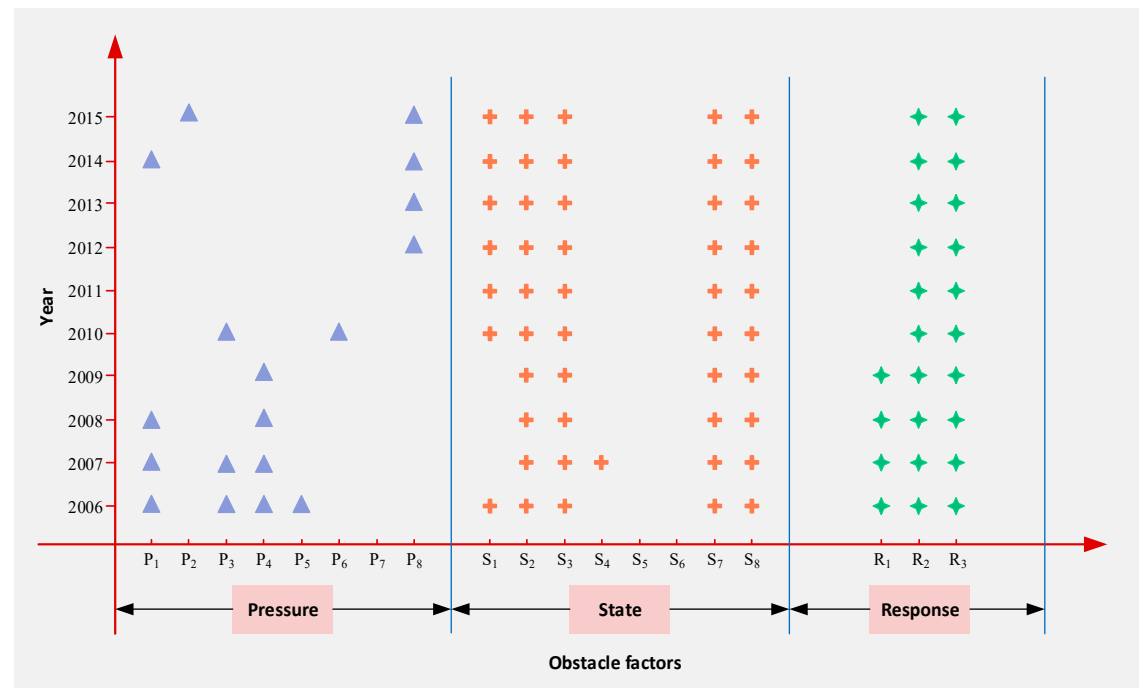

Figure 4. A scatter diagram of obstacle factors of natural gas comprehensive security index from 2006 to 2015.

There were also some changes in the barriers affecting natural gas security from 2006 to 2015. In 2006, China's natural gas comprehensive security index was 0.627. Population growth pressure, environmental pressure, low reserve-production ratio, high concentration of imports in the market, a lack of construction of domestic natural gas infrastructure, and a lack of resources development investment, and emergency support levels were all impediments to security during this period. From 2006 to 2008, the comprehensive natural gas security index rose rapidly. In 2008, the comprehensive natural gas security index was 0.721 , and the obstacle factor decreased from 14 in 2006 to 9 in 2008. In 2009, the comprehensive natural gas security index reached a peak of 0.740 . During this period, the barrier factor was reduced to 8 . The main obstacles during that time period were carbon emission reduction pressure (P4), world reserve ratio (S2), market concentration (S3), 
natural gas pipeline construction (S7), gas source guarantee rate (S8), resource development (R1), and emergency support (R2, R3).

In 2010, the comprehensive natural gas security index showed a downward trend for the first time. During this period, the obstacle factor increased to 10, and the economic growth pressure, environmental pollution control pressure, and storage-production ratio once again became obstacles to natural gas security. This indicates economic development and environmental pollution have a certain impact on natural gas security, and the low storage-production ratio directly affects domestic natural gas production. The natural gas security maintained a downward trend from 2011 to 2014, but the comprehensive natural gas security index recovered again in 2015. Based on the obstacle factors in 2011 (storage ratio, world reserve ratio, market concentration, supply security, and emergency support), we conclude that the obstacle factors from 2012 to 2015 were mainly caused by population growth pressure, urban development pressure, and supply-demand ratio. Therefore, social pressure is another important factor affecting natural gas security in addition to infrastructure and government response measures.

\subsubsection{Obstacle Degree Analysis on China's Natural Gas Security from 2016 to 2025}

Using the obstacle model to diagnose the obstacles affecting China's natural gas security from 2016 to 2025, as shown in Figure 5, the key obstacles leading to the low natural gas comprehensive security index are: Urban development pressure (P2), supply-demand ratio (P8), reserve-production ratio (S1), LNG import price (S5), natural gas consumption growth pressure (P7), world reserve ratio (S2), domestic price volatility (S4), import dependence (S6), natural gas pipeline construction (S7), the gas source guarantee rate (S8), natural gas storage capacity (R2), and natural gas supply (R3). Specifically, the average obstacle degree of the reserve-production ratio (S1) is $17.84 \%$, the average obstacle degree of supply-demand ratio (P8) is $10.62 \%$, and the average obstacle degree of LNG import price volatility (S5) is $10.35 \%$. The average obstacle from urban development pressure (P2) is $9.57 \%$. The obstacles of the four types of obstacles tend to increase monotonously from 2016 to 2025, while the import dependence (S6) will represent more than 5\% of obstacles from 2018. Continuing this increasing trend, the obstacle of import dependence (S6) will reach $19.32 \%$ by 2025 . This shows that on the one hand, these five types of obstacle factors will be the most important obstacle factors affecting China's natural gas security in the next decade. On the other hand, the main internal factors affecting China's natural gas security will shift from the lack of adequate natural gas pipeline construction and gas storage facilities construction to low natural gas exploitation and increased urbanization, which will increase the pressure on natural gas supply and demand. The main external factors affecting China's natural gas security will shift from higher market concentration to natural gas import prices and dependence.

There are also some changes in the obstacle factors affecting natural gas security from 2016 to 2025. In 2016, China's natural gas comprehensive security index was 0.669. Urban development pressure, low supply and demand, weak resource endowment, natural gas domestic price and LNG import price fluctuations, supply security, and low levels of emergency support were all obstacle factors during this period. In 2016, the number of obstacle factors was 10, and the obstacle factor was reduced to 9 from 2017 to 2020. In 2017, the obstacle factor reduced the domestic price volatility of natural gas based on 2016, and the barrier factor was the same from 2018 to 2020. It has increased the pressure on natural gas consumption growth and reduced the proportion of world reserves. It shows that with the increase of China's natural gas reserves, the proportion of world reserves in the near future will no longer be the main obstacle factor.

The number of obstacle factors were reduced to seven from 2021 to 2022 with natural gas supply no longer an important obstacle factors compared to 2020. It is worth noting that since 2021, the gas source guarantee rate (S8) and natural gas supply (R3) are no longer major obstacle factors, but both indicators are obstacle factors to gas security between 2006 and 2020. The natural gas pipeline construction (S7) is an obstacle factor to natural gas security from 2006 to 2022, indicating that the speed of natural gas 
infrastructure construction will increase with the current consumption demand of natural gas. It is expected that the supply guarantee level of natural gas will be greatly improved by 2022 and will not be a major obstacle to the security of natural gas in the short term.

The obstacle factor remains unchanged from 2023 to 2025, mainly due to urban development pressure (P2), natural gas consumption growth pressure (P7), supply-demand ratio (P8), storage-production ratio (S1), LNG import price volatility (S5), and import dependence (S6). This factor suggests that with the development of urbanization, natural gas consumption increases, and the supply becomes in shortage for the nation. On the one hand, it is necessary to speed up the research and development of natural gas mining technology, and to effectively develop ways to use natural gas more efficiently. On the other hand, the government should increase its diplomatic efforts, to control the import price of LNG and the dependence of natural gas import within a reasonable range, to prepare for the strategic goal of achieving the upper limit of 50\% of China's natural gas dependence by 2035.

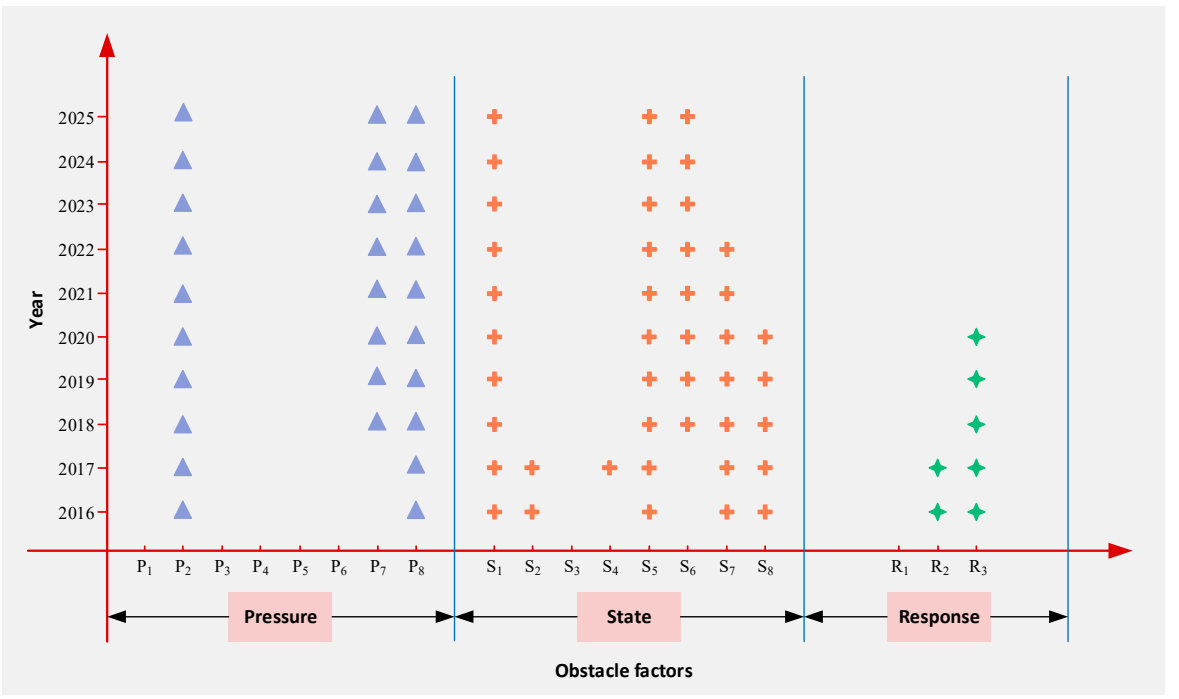

Figure 5. A scatter diagram of obstacle factors of natural gas comprehensive security index from 2016 to 2025.

\subsubsection{Contributions, Limitations, and Future Perspective}

The main contributions of this paper are listed as follows:

(1) Based on previous literature and SDG7 in 2030 Agenda, we specifically propose the definition of natural gas security, unlike most existing literature, to focus on the perspective of supply security. This paper concludes that natural gas security is a state, meaning that a country or region obtains a sufficient, reliable, affordable, and continuous supply at a specified time and place, that is: Adequate natural gas resources to meet the needs of national or regional economic development, social stability, and national security. Notably, we have enriched the conception of natural gas security using a multi-dimension approach.

(2) According to the definition mentioned above and based on the PSR model, we constructed a comprehensive evaluation system to calculate China's national natural gas comprehensive security index using the exponential weighting method.

(3) We used a GM $(1,1)$ model to predict the development tendency of China's natural gas security from 2016 to 2025, illustrating the evolutionary trajectory of China's natural gas security from 2006 to 2025. Figure 3 shows the trending of China's natural gas security from 2006 to 2025 with mild fluctuations. Figure 6 shows the response index increases from 2006 to 2025, while the pressure index decreases before 2020 and bounces back between 2020 and 2025. This observation indicates China's natural gas security will be under control as response measures are increasingly applied. In addition, the natural gas security state is also expected to improve in the future. 
(4) Different from the existing literature, this paper has adopted an obstacle degree model to perform a detailed investigation of the key factors affecting natural gas security, in addition to performing the security analysis and prediction. We concluded that low natural gas exploitation and increased urbanization are the main internal factors that will affect China's natural gas security from 2016 to 2025. This conclusion has been evaluated in the research done by Jian Chai et al. [58], who also claim that fossil energy structures and non-clean energy structures also affect natural gas security. In addition, external factors affecting China's natural gas security include prices of imported gas and the degree of import dependence. Ting Wang et al. [30] reached a similar conclusion. The most urgent issue in rising foreign gas dependence for China is gas price. In recent years, there have been some fluctuations in the international market price of natural gas, but the overall trend of international prices of natural gas is rising, especially in the long run. Compared to oil, natural gas is difficult to store and replace in the short-term. With the continuous increase in China's foreign gas dependence, price control of exporting countries will increase. In this sense, we adopted an obstacle degree model to evaluate the feasibility of adopting these key factors, which are of great significance for governments to establish energy security policies.

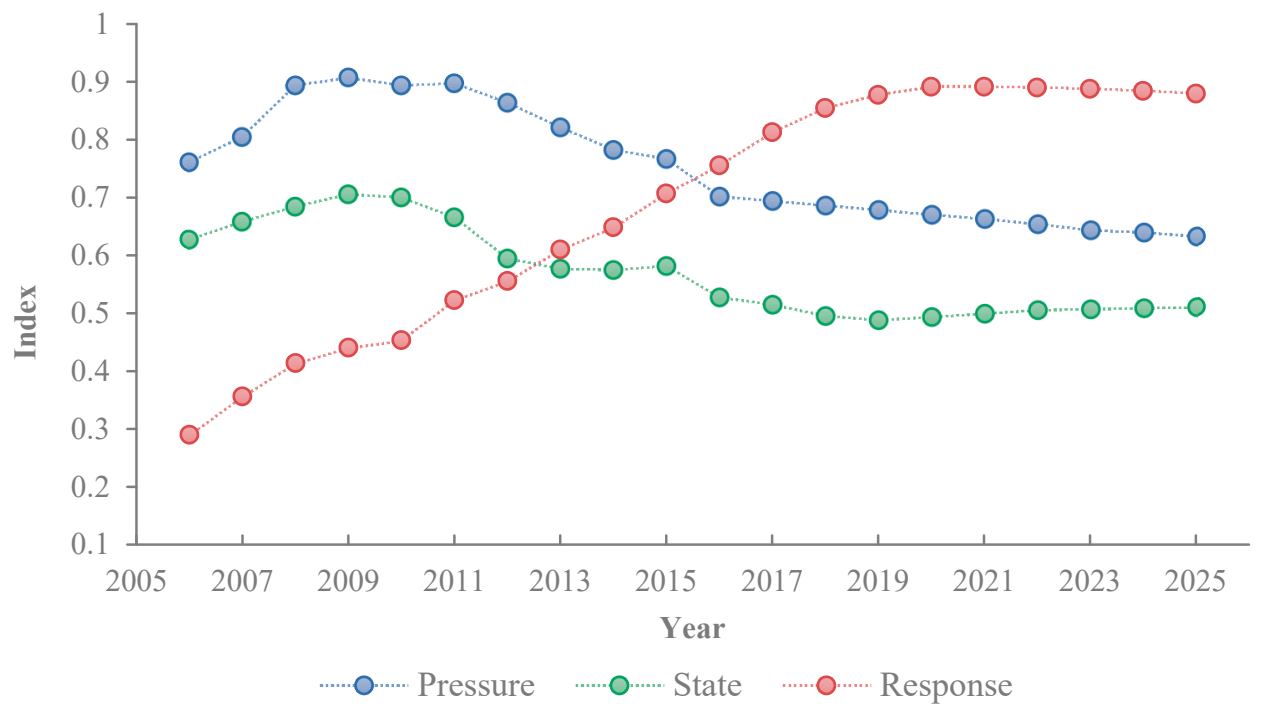

Figure 6. Trend of China's natural gas security pressure-state-response from 2006 to 2025.

However, our study has several limitations. Firstly, China has started importing natural gas from other countries since 2006. Moreover, due to the availability and accessibility of data, the time span of selected data in this research is from 2006 to 2015. If we use ten years of data to predict the development of next 15 years, the time period is too long, and the results obtained would be less accurate. Therefore, in order to better reflect the development trend of natural gas security, this paper only made predictions until 2025. Secondly, research on natural gas security can vary with differing perspectives. China's natural gas security assessment index system constructed in this paper is only based on the current background of national energy transition. If China has new alternative energy sources or can be widely mined in the future, with the emergence of new energy sources, the natural gas security evaluation index system constructed in this paper will be further improved. Thirdly, this paper focuses on two factors (i.e., the affordability and balance of natural gas supply and demand) for evaluating China's natural gas supply security. The fossil energy structure and non-clean energy structure is currently out of the scope of the proposed research and will be considered in our future work.

Additionally, as the natural gas market in China is less liberalized nowadays, more attention should be paid to issues related to China's natural gas security under deregulation. Meanwhile, we will 
focus on China's energy SDG targets for 2030 Agenda by breaking the agenda down point by point with the concurrent national energy policies in our future study.

\section{Conclusions and Policy Implications}

\subsection{Conclusions}

Natural gas security is inextricably linked with China's economic development, social security, and stability. This paper introduced a PSR (pressure-state-response) analysis framework to systematically evaluate China's natural gas security using an exponential weighting method, as well as a $\operatorname{GM}(1,1)$ model to forecast its future security tendencies. Based on the predicted and past trajectories of the nation's natural gas security evolution, we developed an obstacle model to diagnose the degree to which key factors impact China's natural gas security.

From 2006 to 2015, China's natural gas comprehensive security index was low and fluctuating between 0.627 and 0.740 . One essential reason was that China's natural gas resource endowment was rather weak compared with the continuously increasing demand, natural gas infrastructure construction lagged behind the need, and resource development efforts and emergency support levels were low. Although other factors, such as environmental, social, and resource pressure had an impact on the security levels, they were not the key reasons for the low level of natural gas security during that time.

From 2016 to 2025, China's natural gas comprehensive security index will be between 0.669 and 0.759. Except for the years of 2016, 2017, and 2025 (which were or are predicted to be lower than 0.7), the natural gas comprehensive security indices in other years are higher than 0.7. The shift of the timeline of the obstacles shows that the obstacles affecting the natural gas comprehensive security index will be mainly contributed by urban development pressure, consumption growth pressure, supply-demand ratio, storage-production ratio, LNG import price volatility, and import dependence.

From 2006 to 2025, China's natural gas comprehensive security will increase with periodic fluctuations. The main internal factors affecting China's natural gas security will shift from the lack of adequate pipeline and gas storage facilities construction to low natural gas exploitation and increased urbanization, which will increase the pressure on the balance of natural gas supply and demand. The main external factors will shift from higher market concentration to prices of imported gas, and the degree of import dependence.

\subsection{Policy Implications}

Essentially, while China's natural gas resources are secure in the short term, in the long run, its natural gas supply security still faces with accelerating urbanization, a high degree of dependence on external dependence sources, and other severe challenges. Based on the above evaluation, prediction, and obstacle degree analysis of China's natural gas security, against a background of national energy transition and accelerating progress toward SDG 7 in 2030 Agenda for Sustainable Development (ensuring access to affordable, reliable, sustainable, and modern energy for all), the policy implications of this study are as follows:

Resource: On one hand, China needs to strengthen its capabilities for self-supply. Increasing the production capacity of domestic natural gas can effectively reduce the dependence on imports. It is necessary to increase investment in internal potentials, improve domestic production capacity, achieve stable production, and increase production of the three gas fields (southwest, Changqing, and Tarim). It is recommended that the government should consider deregulating the upstream exploration and development access restrictions and encourage more companies, especially private enterprises, to participate. In addition, it is recommended that relevant departments may provide more preferential environments for the exploration and development of unconventional natural gas resources such as shale gas, tight gas, and coalbed methane. On the other hand, the government should re-evaluate import risks and build a more diversified resource import system. Based on comprehensive geopolitical considerations, China should optimize the source country structure of natural gas imports to ensure 
the stability of supply, for example, transferring from politically unstable countries or regions to those stable ones, such as more LNG importing from the U.S.

Infrastructure: It is necessary to strengthen the interconnection of domestic natural gas pipelines and rationally deploy more gas storage and LNG facilities. Another important task is to ensure the security of foreign natural gas supply channels. China should reduce its dependence on high-risk transportation routes and nodes, and actively promote the progress of pipeline projects such as the Sino-Russian and Central Asian natural gas pipelines; it should also strengthen marine disaster warning services and improve the accuracy of disaster prediction. The cooperation with suppliers and transit countries should also be strengthened to ensure greater security of international transportation channels.

Technology: In the era of energy transformation and accelerated urbanization, improving natural gas utilization efficiency is very arduous and relies on scientific and technological progress and innovation. The goal in this work should be to increase gas consumption and output value per unit. Moreover, unconventional natural gas science and technology research and development efforts should be considered as a key component to breakthrough technical bottlenecks and increase natural gas reserves and efficiency.

Market: In China, the natural gas market has not been fully liberalized. While external policy-focused implementations are valuable, there are also internal measures that will be of utmost importance, such as improving the domestic natural gas price formation and implementing demand-side management. Significantly, the focus of future pricing reforms will be to further deepen the management of pipeline transportation prices, strengthen the regulation of gas distribution prices, and promote the construction of natural gas trading centers, which will ensure domestic consumers will be provided with not only stable and affordable fuel, but a decrease in wasted resources.

In fact, the natural gas system is a hydraulic system and a slight move in one part may affect the whole system. Therefore, in order to keep the natural gas system secure as a whole, policy makers should adopt systematic approaches which take into account all the potential factors that can affect the system.

Author Contributions: Conceptualization, M.G. and Y.B.; Data curation, Y.B.; Formal analysis, Y.B. and Z.J.; Funding acquisition, M.G. and J.C.; Methodology, Y.B.; Project administration, M.G. and J.C.; Resources, J.C.; Software, Y.B.; Supervision, J.C. and Z.J.; Validation, Z.J.; Visualization, J.C. and Z.J.; Writing-original draft, M.G., Y.B. and Z.J.; Writing-review \& editing, M.G., Y.B. and J.C.

Funding: This research was funded by The Ministry of education of Humanities and Social Science Project, China (grant number 11YJC790052), Fundamental Research Funds for Central Universities, China University of Geosciences (Wuhan) (grant number 1810491T09), National Social Science Fund, China (grant number 18ZDA049), Geological Survey Fund of China (grant number 2017086020) and China Scholarship Council (grant number 201706415059).

Acknowledgments: We thank the editor, the special issue editor, and the anonymous reviewers for their constructive comments, which will significantly improve the quality of the paper.

Conflicts of Interest: The authors declare no conflict of interest.

\section{References}

1. Shukla, A.S. Energy Security and Sustainability; CRC Press: Boca Raton, FL, USA, 2016.

2. Proskuryakova, L. Updating energy security and environmental policy: Energy security theories revisited. J. Environ. Manag. 2018, 223, 203-214. [CrossRef] [PubMed]

3. Oil and Gas Department NEA, C.I.; Center for Oil and Gas Resource Strategies MoLaR. China Natural Gas Development Report 2018; Petroleum Industry Press: Beijing, China, 2018.

4. Winzer, C. Conceptualizing energy security. Energy Policy 2012, 46, 36-48. [CrossRef]

5. Shaikh, F.; Ji, Q.; Fan, Y. Evaluating China's natural gas supply security based on ecological network analysis. J. Clean. Prod. 2016, 139, 1196-1206. [CrossRef]

6. Ren, J.; Sovacool, B.K. Quantifying, measuring, and strategizing energy security: Determining the most meaningful dimensions and metrics. Energy 2014, 76, 838-849. [CrossRef] 
7. Dyer, H.; Trombetta, M.J. The concept of energy security: Broadening, deepening, transforming. In International Handbook of Energy Security; Dyer, H., Trombetta, M.J., Eds.; Edward Elgar Publishing: Cheltenham, UK, 2013; pp. 3-18.

8. European Commission. The EU Energy Policy: Engaging with Partners beyond Our Borders; European Commission: Brussels, Belgium, 2011.

9. International Energy Agency. Energy Supply Security: The Emergency Response of IEA Countries, 2014th ed.; International Energy Agency: Paris, France, 2014.

10. Radovanovic, M.; Filipovic, S.; Pavlovic, D. Energy security measurement-A sustainable approach. Renew. Sustain. Energy Rev. 2017, 68, 1020-1032. [CrossRef]

11. Augutis, J.; Krikstolaitis, R.; Martisauskas, L.; Peciulyte, S. Energy security level assessment technology. Appl. Energy 2012, 97, 143-149. [CrossRef]

12. Cherp, A.; Jewell, J. The three perspectives on energy security: Intellectual history, disciplinary roots and the potential for integration. Curr. Opin. Environ. Sustain. 2011, 3, 202-212. [CrossRef]

13. Chester, L. Conceptualising energy security and making explicit its polysemic nature. Energy Policy 2010, 38, 887-895. [CrossRef]

14. Nyman, J. Energy and Security: Discourse and Practice in the United States and China. Ph.D. Thesis, University of Birmingham, Birmingham, UK, 2014.

15. Li, J.; Dong, X.; Shangguan, J.; Hook, M. Forecasting the growth of China's natural gas consumption. Energy 2011, 36, 1380-1385. [CrossRef]

16. Zhang, M.; Su, M.; Lu, W.; Su, C. An Assessment of the Security of China's Natural Gas Supply System Using Two Network Models. Energies 2015, 8, 13710-13725. [CrossRef]

17. Lu, W.; Su, M.; Fath, B.D.; Zhang, M.; Hao, Y. A systematic method of evaluation of the Chinese natural gas supply security. Appl. Energy 2016, 165, 858-867. [CrossRef]

18. Pavlović, D.; Banovac, E.; Vištica, N.J.E.P. Defining a composite index for measuring natural gas supply security-The Croatian gas market case. Energy Policy 2018, 114, 30-38. [CrossRef]

19. Biresselioglu, M.E.; Yelkenci, T.; Oz, I.O. Investigating the natural gas supply security: A new perspective. Energy 2015, 80, 168-176. [CrossRef]

20. Berk, I.; Ediger, V.S. A historical assessment of Turkey's natural gas import vulnerability. Energy 2018, 145, 540-547. [CrossRef]

21. Geng, J.-B.; Ji, Q.; Fan, Y.; Shaikh, F. Optimal LNG importation portfolio considering multiple risk factors. J. Clean. Prod. 2017, 151, 452-464. [CrossRef]

22. Abada, I.; Massol, O. Security of supply and retail competition in the European gas market. Some model-based insights. Energy Policy 2011, 39, 4077-4088. [CrossRef]

23. Lochner, S. Modeling the European natural gas market during the 2009 Russian-Ukrainian gas conflict: Ex-post simulation and analysis. J. Nat. Gas Sci. Eng. 2011, 3, 341-348. [CrossRef]

24. Flouri, M.; Karakosta, C.; Kladouchou, C.; Psarras, J. How does a natural gas supply interruption affect the EU gas security? A Monte Carlo simulation. Renew. Sustain. Energy Rev. 2015, 44, 785-796. [CrossRef]

25. Lise, W.; Hobbs, B.F.; van Oostvoorn, F. Natural gas corridors between the EU and its main suppliers: Simulation results with the dynamic GASTALE model. Energy Policy 2008, 36, 1890-1906. [CrossRef]

26. Cabalu, H. Indicators of security of natural gas supply in Asia. Energy Policy 2010, 38, 218-225. [CrossRef]

27. Holz, F.; von Hirschhausen, C.; Kemfert, C. Perspectives of the European Natural Gas Markets Until 2025. Energy J. 2009, 30, 137-150. [CrossRef]

28. Suganthi, L.; Samuel, A.A. Energy models for demand forecasting-A review. Renew. Sustain. Energy Rev. 2012, 16, 1223-1240. [CrossRef]

29. Parikh, J.; Biswas, C.R.D.; Singh, C.; Singh, V. Natural Gas requirement by fertilizer sector in India. Energy 2009, 34, 954-961. [CrossRef]

30. Wang, T.; Lin, B. Impacts of unconventional gas development on China's natural gas production and import. Renew. Sustain. Energy Rev. 2014, 39, 546-554. [CrossRef]

31. Brown, S.P.A.; Yucel, M.K. What drives natural gas prices? Energy J. 2008, 29, 45-60. [CrossRef]

32. Brown, S.R.A.; Yucel, M.K. Market Arbitrage: European and North American Natural Gas Prices. Energy J. 2009, 30, 167-185. [CrossRef]

33. Nick, S.; Thoenes, S. What drives natural gas prices? A structural VAR approach. Energy Econ. 2014, 45, 517-527. [CrossRef] 
34. Zhang, D.; Shi, M.; Shi, X. Oil indexation, market fundamentals, and natural gas prices: An investigation of the Asian premium in natural gas trade. Energy Econ. 2018, 69, 33-41. [CrossRef]

35. Westphal, K. Institutional change in European natural gas markets and implications for energy security: Lessons from the German case. Energy Policy 2014, 74, 35-43. [CrossRef]

36. Spanjer, A. Russian gas price reform and the EU-Russia gas relationship: Incentives, consequences and European security of supply. Energy Policy 2007, 35, 2889-2898. [CrossRef]

37. Leahy, E.; Devitt, C.; Lyons, S.; Tol, R.S.J. The cost of natural gas shortages in Ireland. Energy Policy 2012, 46, 153-169. [CrossRef]

38. Orlov, A. An assessment of optimal gas pricing in Russia: A CGE approach. Energy Econ. 2015, 49, 492-506. [CrossRef]

39. Kiriyama, E.; Kajikawa, Y. A multilayered analysis of energy security research and the energy supply process. Appl. Energy 2014, 123, 415-423. [CrossRef]

40. Umbach, F. Global energy security and the implications for the EU. Energy Policy 2010, 38, 1229-1240. [CrossRef]

41. Mansson, A.; Johansson, B.; Nilsson, L.J. Assessing energy security: An overview of commonly used methodologies. Energy 2014, 73, 1-14. [CrossRef]

42. Kisel, E.; Hamburg, A.; Haerm, M.; Leppiman, A.; Ots, M. Concept for Energy Security Matrix. Energy Policy 2016, 95, 1-9. [CrossRef]

43. Li, Y.; Shi, X.; Yao, L. Evaluating energy security of resource-poor economies: A modified principle component analysis approach. Energy Econ. 2016, 58, 211-221. [CrossRef]

44. Prambudia, Y.; Nakano, M. Integrated Simulation Model for Energy Security Evaluation. Energies 2012, 5, 5086-5110. [CrossRef]

45. Proskuryakova, L. Energy technology foresight in emerging economies. Technol. Forecast. Soc. Chang. 2017, 119, 205-210. [CrossRef]

46. Narula, K.; Reddy, B.S. A SES (sustainable energy security) index for developing countries. Energy 2016, 94, 326-343. [CrossRef]

47. Jokar, P.; Arianpoo, N.; Leung, V.C.M. A survey on security issues in smart grids. Secur. Commun. Netw. 2016, 9, 262-273. [CrossRef]

48. Kessides, I.N.; Kuznetsov, V. Small Modular Reactors for Enhancing Energy Security in Developing Countries. Sustainability 2012, 4, 1806-1832. [CrossRef]

49. Shin, J.; Shin, W.-S.; Lee, C. An energy security management model using quality function deployment and system dynamics. Energy Policy 2013, 54, 72-86. [CrossRef]

50. Organization for Economic Co-Operation and Development (OECD). OECD Core Set of Indicators for Environmental Performance Reviews: A Synthesis Report by the Group on the State of the Environment; Organization for Economic Co-Operation and Development: Paris, France, 1993; pp. 5-10.

51. Guo, M.J.; Li, W.J.; Wang, W.S. Simulation and Evaluation of China's Natural Gas Resource Security Evolution Trajectory Based on PSR Model. Adv. Mater. Res. 2014, 953-954, 720-729. [CrossRef]

52. Zhu, H.; Zhang, A. Analysis on the Differences of Cultivated Land Resource Quantity Security on Time and Space in China. China Popul. Resour. Environ. 2006, 16, 113-117.

53. British Petroleum Company. BP Statistical Review of World Energy; British Petroleum Company: London, UK, 2018.

54. China NBoSotPsRo. China Statistical Yearbook, 2006-2016; China Statistics Press: Beijing, China, 2017.

55. China NBoSotPsRo. China Energy Statistical Yearbook, 2006-2016; China Statistics Press: Beijing, China, 2017.

56. China NBoSotPsRo. China Urban Construction Statistical Yearbook 2006-2016; China Statistics Press: Beijing, China, 2017.

57. Mao, C.; Li, M. Influence and countermeasures of adjustment of childbearing policy on demographic bonus. China Popul. Resour. Environ. 2016, 26, 170-176.

58. Chai, J.; Liang, T.; Lai, K.K.; Zhang, Z.G.; Wang, S.J.E.P. The future natural gas consumption in China: Based on the LMDI-STIRPAT-PLSR framework and scenario analysis. Energy Policy 2018, 119, 215-225. [CrossRef]

(C) 2018 by the authors. Licensee MDPI, Basel, Switzerland. This article is an open access article distributed under the terms and conditions of the Creative Commons Attribution (CC BY) license (http:/ / creativecommons.org/licenses/by/4.0/). 